\title{
Phytophagous mites on genetically modified maize with Bacillus thuringiensis genes
}

\author{
Tamara Esteves Ferreira ${ }^{1}$ Marcos Antonio Matiello Fadini ${ }^{*}$ \\ Simone Martins Mendes ${ }^{2}$ Cidália Gabriela Santos Marinho ${ }^{1}$ Ivan Cruz ${ }^{2}$
}

${ }^{1}$ Universidade Federal de São João Del-Rei (UFSJ), 563, 5701-970, Sete Lagoas, MG, Brasil. E-mail: fadini@ufsj.edu.br. "Corresponding author.

${ }^{2}$ Embrapa Milho e Sorgo, Sete Lagoas, MG, Brasil.

ABSTRACT: The study of non-target organisms such as mites, can provide information about the possible effects of transgenic maize cultivars on the arthropod community. This study aimed to evaluate the abundance of phytophagous mites in the area of Bt maize and evaluate the instantaneous population growth rate, and food preference of phytophagous mites on Bt maize. We registered the species occurrence and the number of adult mite individuals on four maize cultivars, one non-Bt 30F35, and three containing the proteins CrylAb (30F35 Yg), CrylF (30F35 Hx) and Vip3a (Impacto Viptera). Cry proteins disrupt the midgut epithelium of insect pests. The food preference and instantaneous population growth rate (ri) were evaluated using the two-spotted spider mite Tetranychus urticae as model. The species Catarhinus tricholaenae and Aceria zeala were recorded. The Bt maize cultivars did not significantly affect the average number of C. tricholaenae and A. zeala mites compared to conventional cultivar. The population growth rates of T. urticae were similar for the different maize cultivars. T. urticae showed no preference between the leaf of Bt or conventional cultivars. Bt maize did not affect the abundance of species in phytophagous mite. Key words: plant defense, Non-target organisms, Genetically modified organisms Bt protein, Diptilomiopidae, Eriophyidae, Tetranychidae.

\section{Ácaros fitófagos em milho geneticamente modificado com genes de Bacillus thuringiensis}

RESUMO: $O$ estudo de organismos não-alvo, tais como ácaros, pode fornecer informações sobre os possíveis efeitos de cultivares de milho transgênico na comunidade de artrópodos. Este estudo teve como objetivo avaliar a abundância de ácaros fitófagos na área de milho Bt e avaliar a taxa de crescimento populacional instantânea e preferência alimentar de ácaros fitófagos em milho Bt. Registramos a ocorrência de espécies e número de indivíduos adultos de ácaros em quatro cultivares de milho, um não-Bt 30F35, e três contendo a proteina Cry $1 \mathrm{Ab}$ (30F35 Yg), CrylF (30F35 Hx) e VIP3A (Impacto Viptera). A preferência alimentar e taxa instantânea de crescimento populacional foram avaliadas utilizando fêmeas adultas do ácaro-rajado Tetranychus urticae. As espécies Catarhinus tricholaenae e Aceria zeala foram registradas. As cultivares de milho Bt não afetaram significativamente o número médio de ácaros $C$. tricholaenae e A. zeala em relação ao cultivar convencional. As taxas de crescimento populacional de T. urticae foram similares para os diferentes cultivares. T. urticae não mostrou preferência entre a folha de milho Bt ou cultivares convencionais. Sugere-se, então, que o milho Bt não afeta a abundância de espécies, preferência alimentar e taxa de crescimento de ácaros fitófagos. Palavras-chave: defesa de plantas, organismos não-alvo, organismos geneticamente modificados, proteina Bt, Diptilomiopidae, Eriophyidae, Tetranychidae.

\section{INTRODUCTION}

Genetically modified (GM) plants that express genes with insecticidal activity represent an efficient control for insect pests, in addition to being an important component of integrated pest management (IPM) (PROKOPY, 1994). The first generations of GM plants resistant to chewing insects were developed with genes encoding insecticidal proteins from the bacterium Bacillus thuringiensis (FISCHHOFF et al., 1987), targeting resistance, mainly to Lepidoptera and Coleoptera (PERLAK et al., 2001). Proteins to be expressed become also exposed to other non-target phytophages and their natural enemies (i.e. predators and parasitoids) (DUTTON et al., 2002, SCHRIJVER et al., 2016). Nevertheless, GM plants containing the $B t$ gene interact with non-target organisms from different trophic levels, harboring not only the insect pests (SCHULER et al., 1999, SCHRIVJER et al., 2016).

Scientific literature that recommends strategies for pest management in maize (Zea mays L.) does not refer to mite populations as key pest (MORAES \& FLECHTMANN, 2008, FADINI et 
al., 2010). The two-spotted spider mite Tetranychus urticae Koch (Acari: Tetranychidae) is an important polyphagous pest of vegetables and other crops (BOLLAND et al., 1998, CAPINERA 2001, OPIT et al., 2004, LIBURD et al., 2007), and can be also find on maize. This mite can cause eventual infestations in leaves of GM and conventional plant, but it is not the target of modified plants with the $B t$ protein.

We evaluated the occurrence of phytophagous mites in conventional and $B t$ maize in a field. The null hypothesis that plant defense conferred by $B t$ maize proteins would not affect the abundance of phytophagous mites was also tested. We also evaluated, under laboratory conditions, if Bt proteins would affect the instantaneous population growth rate and the feeding preference of the phytophagous mite $T$. urticae.

\section{MATERIALS AND METHODS}

We recorded the occurrence of phytophagous mite species on four maize cultivars: a non- $B t 30 \mathrm{~F} 35$, and three containing the proteins Cry1Ab, (30F35 Yield Gard, Yg, Pioneer ${ }^{\circledR}$ ) and Cry1F (30F35 Herculex, Hx, Pioneer ${ }^{\mathbb{R}}$ ) and Vip3a (Impacto Viptera, Syngenta ${ }^{\circledR}$ ). These cultivars have as target pest some caterpillars, as fall armyworm Spodoptera frugiperda (J.E. Smith) (Lepidoptera: Noctuidae). The experimental area used was in Embrapa Milho e Sorgo, Sete Lagoas, Minas Gerais State, Brazil (19² $8^{\prime}$ 'south latitude, and $44^{\circ} 15^{\prime} 08^{\prime}$ " west longitude GrW).

From June 2013 to September 2013, fortnightly, $B t$ and non- $B t$ maize leaf samples were collected in the experimental plot. The experiment was a completely randomized design with maize cultivars as treatments. The field conditions were homogeneous and do not justified the adoption of blocks. Each cultivar was located in a 100x100m plot area. Four maize leaves were considered as a sampling unit (=replication). For data analysis we used a splitplot analysis of variance, having the factor cultivar with the main plot and the sample unit collection times at 5\% significance in the sub-plot (CRAWLEY, 2007). The statistical program $R$ (R Development Core Team 2015) was used for the data analysis.

Mites specimens reported were mounted on slides with Hoyer medium (MORAES \& FLECHTMANN, 2008) and the best mountings were sent for taxonomic identification confirmation. Slides with Catarhinus tricholaenae specimens were deposited in the mite collection of the Laboratory of Entomology of the Federal University of São João Del-Rei, Campus Sete Lagoas, in the state of Minas Gerais, Brazil.
The food preference and instantaneous growth rate of phytophagous mite $T$. urticae adult females were evaluated in four maize cultivars, three of them expressing Cry and Vip proteins, as described above. Tests were conducted in insect growth chamber incubator at $25 \pm 1{ }^{\circ} \mathrm{C}, \quad 70 \pm 10 \%$ $\mathrm{RH}$ and $12 \mathrm{~h}$ photophase. Mites were collected on sorghum (Sorghum bicolor L.) plants grown in $5 \mathrm{~L}$ plastic pots, containing sandy soil and maintained in a greenhouse. Mites were also reared in laboratory, on non-transgenic maize leaves in plastic cups with water. Although, the T. urticae mite is not a key pest in maize, this species was used as a biological model.

Three $\mathrm{cm}$ diameter leaf discs, obtained from the central part of median leaves of $B t$ and non$B t$ maize were used. Plants were in the phrenological stage V4. Discs were cut and individually placed in three $\mathrm{cm}$ diameter Petri dishes with the underside surface upwards. A piece of water-soaked cotton was inserted inside the Petri plate to keep the leaf moist and prevent the escape of the mites. Five fertilized $T$. urticae females with about three days were obtained from the rearing and maintained in insect growth chamber incubator were released in the middle portion of the leaf with the help of brush. After $96 \mathrm{~h}$ the number of females and the number of eggs deposited were evaluated. Four treatments of $B t$ variety vs non- $B t$ were used in 30 replications ( 150 females per treatment).

The effect of the cultivars on the biology of T. urticae was evaluated by the instantaneous population growth rate (ri) (STARK et al., 1997). Three $B t$ vs non- $B t$ (Impacto Viptera (transgenic) $\mathrm{x}$ 30F35 Conventional, 30F35 HX (transgenic) x 30F35 Conventional and 30F35 YG (transgenic) x 30F35 Conventional) treatments were used in 30 females liberations. Leaf discs of three $\mathrm{cm}$ in diameter obtained from the central part of median leaves a non-Bt 30F35 maize, and three containing the proteins Cry $1 \mathrm{~F}$ (30F35 Hx), Cry 1AB (30F35 Yg) and Vip3a (Impacto Viptera) were used. The discs $(2 \mathrm{~cm} \emptyset)$ were cut out and attached with plastic adhesive tape (Durex $\left.{ }^{\circledR}, 3 \mathrm{M}\right)$. Bt and non-Bt (leaf discs) were glued in adjacent faces; so that, $B t$ face as well as the non- $B t$ face were present on both sides of the disc. Discs were individually placed in a $3 \mathrm{~cm}$ diameter petri plate, on a piece of cotton soaked in water to keep the leaf wet. One fertilized female of T. urticae was released on the plastic adhesive tape with the aid of brush. Light was homogeneous into the rearing chamber and it does not influenced the mite behavior. After $24 \mathrm{~h}$ and $48 \mathrm{~h}$ food preference per leaf surface and number eggs deposited on each face of the disc were evaluated. Females not found and who did not have choice were removed from the analysis. 
Results were evaluated by Kruskal-Wallis test (nonparametric) e and the chi-square test at 5\% significance (CRAWLEY 2007), using the $\mathrm{R}$ statistical package ( $\mathrm{R}$ Development Core Team, 2011).

\section{RESULTS}

Phytophagous mite species found on maize leaves were Catarhinus tricholaenae Keifer (Acari: Diptilomiopidae) and Aceria zeala (Keifer) (Acari: Eriophyidae). No predatory mite species were reported. The $B t$ maize varieties (Cry1Ab (30F35 Yg), Cry1F (30F35 Hx) and Vip3a (Impacto Viptera) did not affect the average number of mites $C$. tricholaenae compared to the conventional cultivar (30F35) $\left(F_{(3,98)}=0.36\right.$, $P=0.78)$. The highest population abundances of mites occurred in the months of August and September, 60 days of experiment. This result suggested that the Cry protein present in $B t$ maize plants did not affect the abundance of $C$. tricholaenae. As expected, the time factor affected the $C$. tricholaenae abundance $\left(F_{(3,98)}=50.3, P<0.01\right)$ (Figure 1).

The varieties of $B t$ maize expressing Cry $1 \mathrm{Ab}$ (30F35 Yg), Cry1F (30F35 Hx) and Vip3a (Impacto Viptera) also did not affect the average number of $A$. zeala mites in relation to the conventional cultivar (30F35) $\left(F_{(3,98)}=1.12, P=0.05\right)$. Time factor affected he abundance of $A$. zeala $\left(F_{(3,98)}=28.0, P<0.01\right)$. This result demonstrated that the Cry protein present in the $B t$ maize varieties did not affect the abundance of $A$. zeala (Figure 2). From 93 adults of $A$. zeala collected, $0.46 \pm 1.21$ individuals were reported on non- $B t$ maize leaves. On $B t$ maize; with Cry1 Ab (30F35 Yg) having $0.37 \pm 1.28$ individuals, Cry1F (30F35 Hx) $0.75 \pm 1.96$ and Vip3a (Impacto Viptera) $0.62 \pm 1.81$ individuals. Instantaneous population growth rate (ri) for T. urticae did not differ when females were maintained on leaf discs of varieties of conventional maize (30F35) and $B t$ (Hx 30F35, 30F35 Yg and Impacto Viptera) $\left(\chi^{2}=67.37, d f=74, P=0.69\right)$ (Figure 3$)$ suggesting that the Cry and Vip proteins, present in Bt maize cultivars, did not affect the instantaneous population growth rate of the phytophagous mite T. urticae.

These results demonstrated also that the Cry protein present in $B t$ varieties did not affect the $T$. urticae foraging per the maize leaf surface. The preference of the phytophagous mite $T$. urticae on leaf surface for feeding and oviposition was not affected by $B t$ maize varieties $(30 \mathrm{~F} 35 \mathrm{Hx}, 30 \mathrm{~F} 35$ $\mathrm{Yg}$ and Impacto Viptera) when compared to the 30F35 Conventional: $30 \mathrm{~F} 35 \mathrm{Hx}$ vs $30 \mathrm{~F} 35\left(\chi^{2}=0.53\right.$, $d f=1, P=0.47) ; 30 \mathrm{~F} 35 \mathrm{Yg}$ vs $30 \mathrm{~F} 35\left(\chi^{2}=0.25, d f=1\right.$, $P=0.65)$ and Impacto Viptera vs $30 \mathrm{~F} 35\left(\chi^{2}=0.00\right.$ $d f=1, P=1) 24$ hours after the release of the females (Figure 4). After 48 hours of the release of the $T$. urticae females on the leaf surfaces, the preferences of the mites was also not affected by $B t$ maize varieties $\left(\chi^{2}=0.05, d f=1, P=0.83\right) ;\left(\chi^{2}=0.05, d f=1\right.$, $P=0.82)$ and $30 \mathrm{~F} 35\left(\chi^{2}=0.22, d f=1, P=0.62\right)$, to the same treatment above (Figure 5).

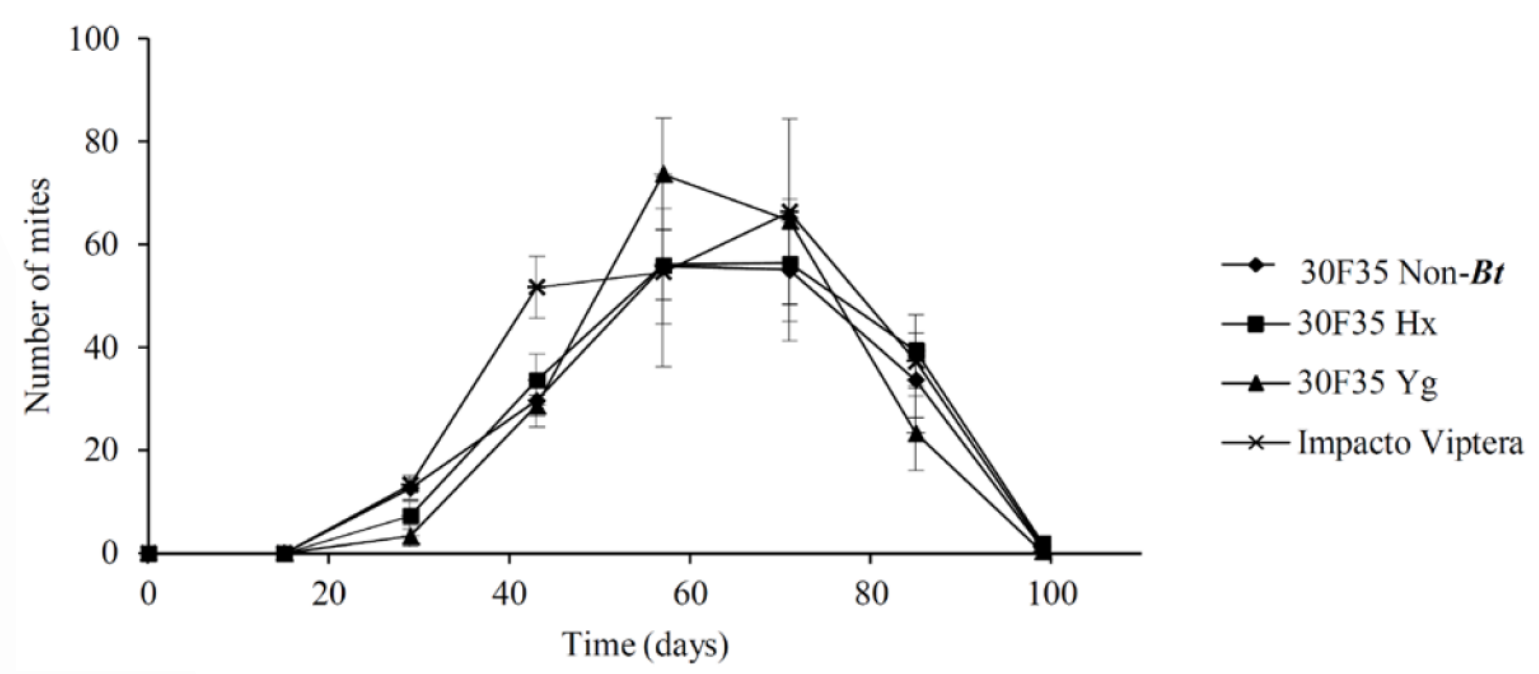

Figure 1 - Mean ( \pm standard error) number of Catarhinus tricholaenae mites on conventional maize (30F35) and Bt Cry1 Ab (30F35 Yg), Cry1F (30F35 Hx) and Vip3a (Impacto Viptera). July to September, 2013. Sete Lagoas, MG, Brazil. 


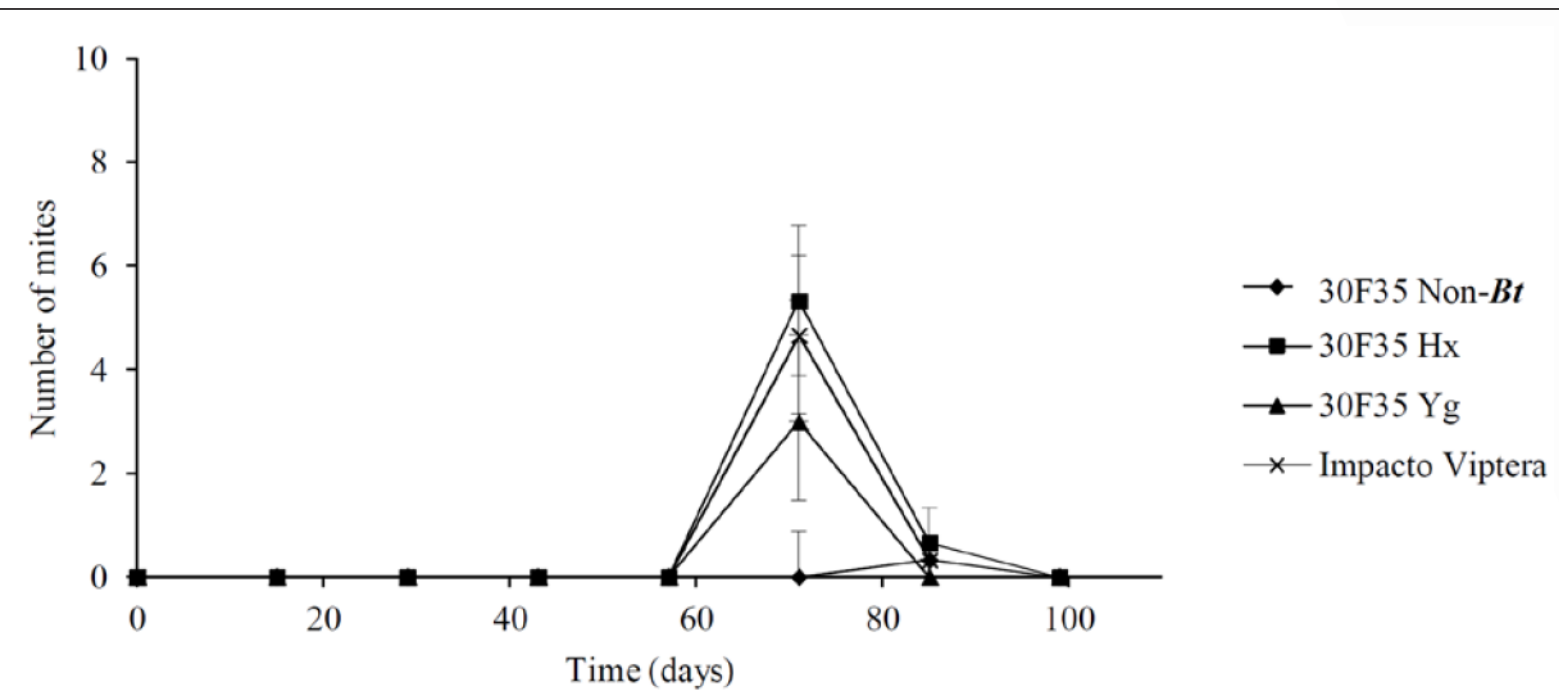

Figure 2 - Mean ( \pm standard error) number of mites Aceria zeala on conventional maize (30F35) and Bt Cry1Ab (30F35 Yg), Cry1F (30F35 Hx) and Vip3a (Impacto Viptera). July to September, 2013. Sete Lagoas, MG, Brazil.

\section{DISCUSSION}

The fact that the numbers of $C$. tricholaenae individuals did not differ among the $B t$ maize varieties Cry1Ab (30F35 Yg), Cry1F (30F35 Hx), Vip3a
(Impacto Viptera) and the non-Bt variety, 30F35 Conventional suggested that the Cry protein did not affect the population abundance of that species. FADINI et al. (2012) reported; however, that the population averages of $C$. tricholaenae on the cultivar

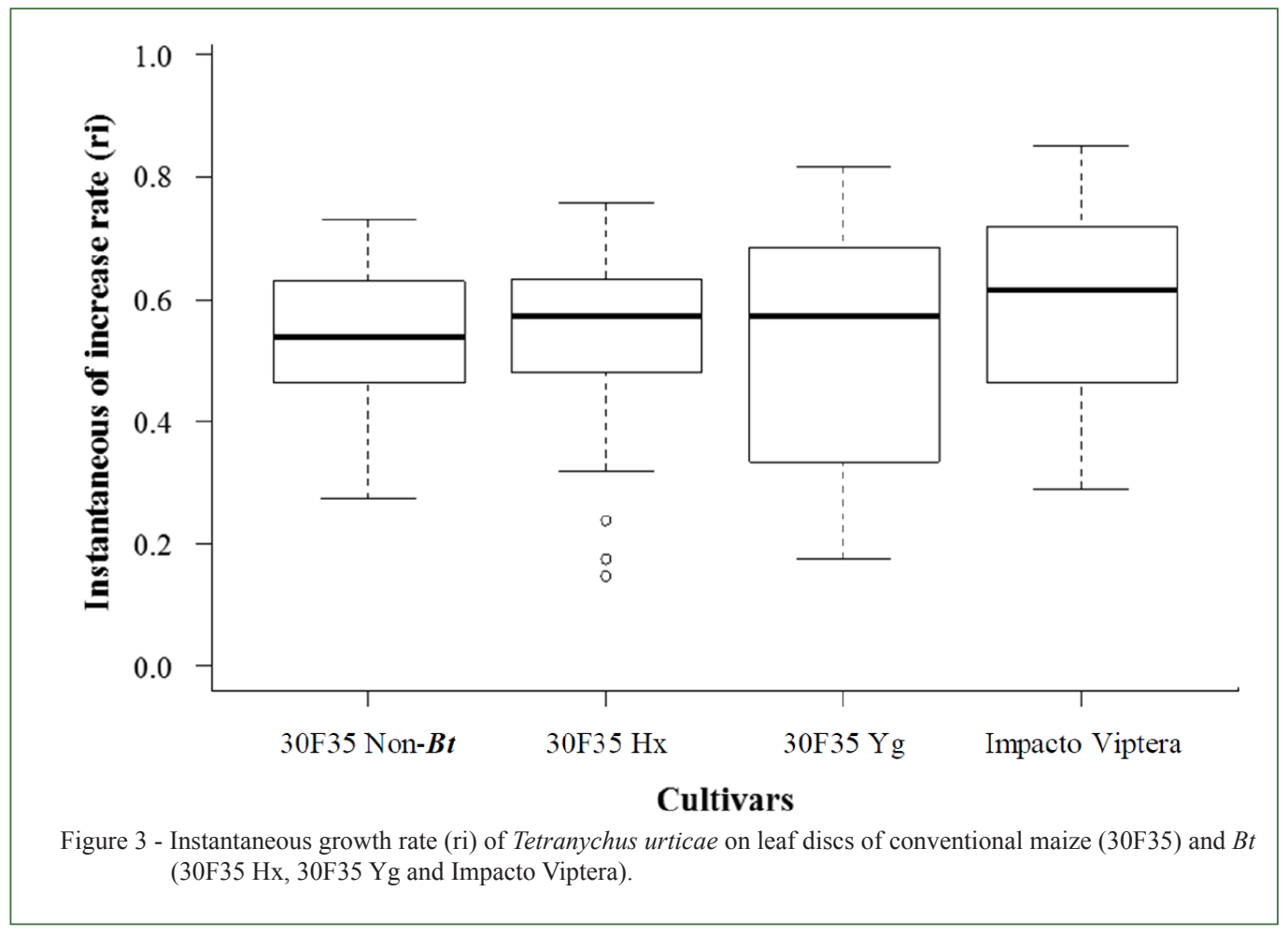

Ciência Rural, v.47, n.10, 2017. 


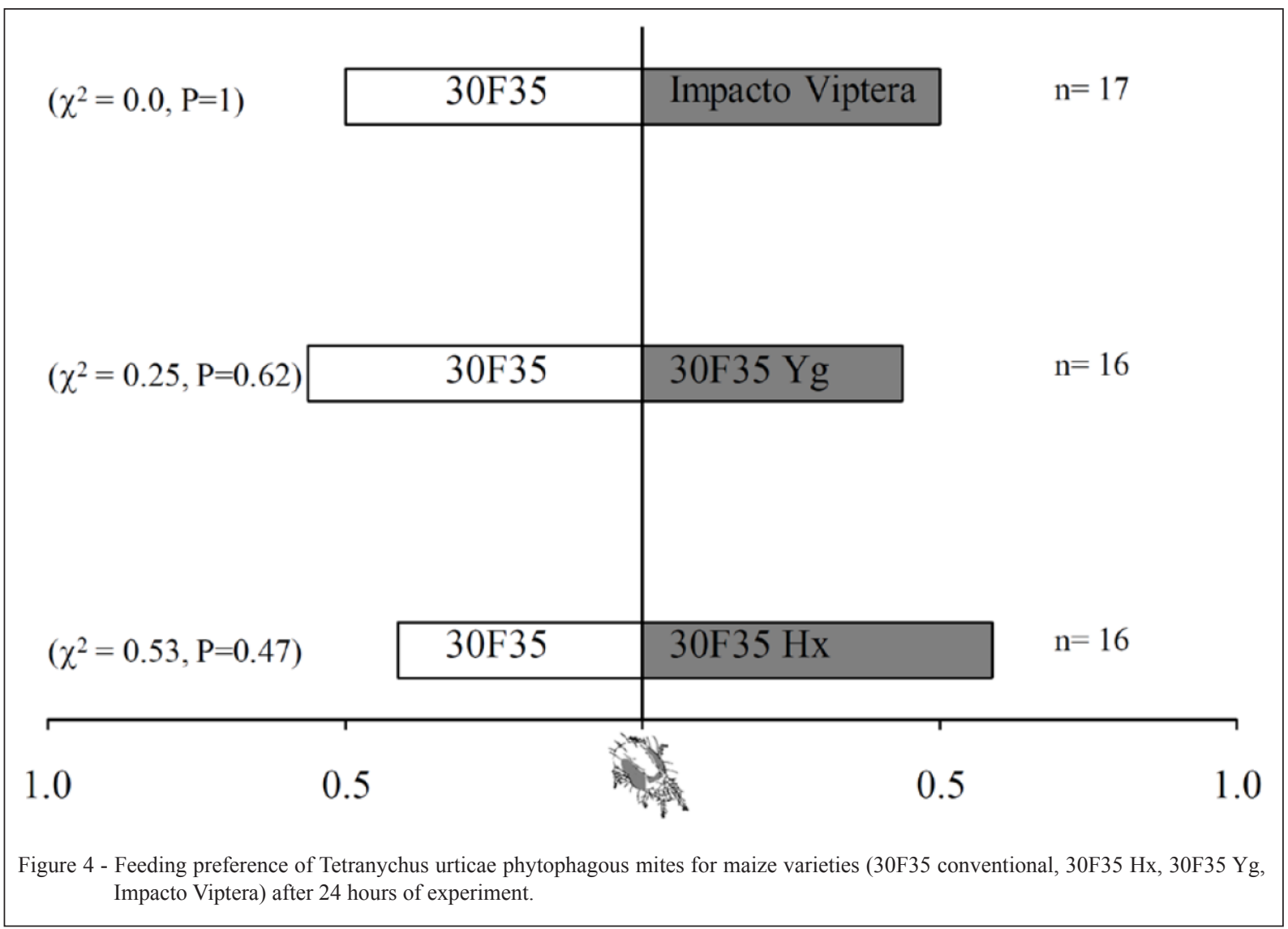

expressing the Cry1 Ab protein were lower when compared to the other cultivars evaluated. A similar effect of the varieties was expected on the abundance of phytophagous mites. The $B t$ maize cultivars Cry1 $\mathrm{Ab}$ (30F35 Yg), Cry1F (30F35 Hx) and Vip3a (Impacto Viptera) also did not affect the abundance of A. zeala, similar to that reported for $C$. tricholaenae.

The estimated average number of mites reported greater population densities of $C$. tricholaenae in August and September. These occurrences may be associated with low rainfall during this period since phytophagous mites correlate to hot and dry periods, in general. In low relative humidity conditions, mites have intensified feeding activity, because they need to ingest more fluid to compensate for their water loss, favoring population growth (VAN DER GEEST, 1985).

The lack of variation in the instantaneous growth rate between treatments may be related to physiological characteristics of the host plant, where the nutritional value of the plant is a determining factor in the choice by phytophagous mites, conferred by secondary compounds. The Cry and Vip proteins in maize plants could promote changes in plant secondary compounds. Thus, the difference in the secondary compound composition could alter the attractiveness of the plant. However, these effects were not observed. There was no significant difference in the instantaneous population growth rate (ri) for $T$. urticae female mites maintained on leaf discs of $B t$ and non- $B t$ varieties when subjected to an environment without food choice. This result demonstrated that the Cry protein present in Bt maize cultivars (30F35 Hx, 30F35 Yg and Impacto Viptera) does not affect the instantaneous growth rate and the feeding preference of T. urticae females while feeding on Bt maize plants.

In food preference tests, there was no difference in free choice combinations of T. urticae mites between varieties $30 \mathrm{~F} 35 \mathrm{Hx}$ vs $30 \mathrm{~F} 35,30 \mathrm{~F} 35$ Yg vs 30F35 and Impacto Viptera vs 30F35. The T. urticae mite demonstrated no preference to the leaf surfaces of both $B t$ and non- $B t$ at 24 hours and 48 hours after release. The non-preference for $B t$ and non- $B t$ maize variety leaf surfaces suggested that the presence of the Cry and Vip proteins in plants did not affect the choice of the feeding site by $T$. urticae. 


\begin{tabular}{|c|c|c|c|}
\hline$\left(\chi^{2}=0.22, \mathrm{P}=0.62\right)$ & $30 F 35$ & Impacto Viptera & $\mathrm{n}=18$ \\
\hline$\left(\chi^{2}=0.05, P=0.82\right)$ & $30 \mathrm{~F} 35$ & $30 \mathrm{~F} 35 \mathrm{Yg}$ & $\mathrm{n}=19$ \\
\hline$\left(\chi^{2}=0.05, \mathrm{P}=0.83\right)$ & $30 \mathrm{~F} 35$ & $30 \mathrm{~F} 35 \mathrm{Hx}$ & $\mathrm{n}=21$ \\
\hline 0.5 & & & \\
\hline
\end{tabular}

\section{CONCLUSION}

Plant defense conferred by the $B t$ maize, Cry and Vip proteins, did not affect the abundance of phytophagous mites in the crop. Proteins present in the $B t$ maize also does not affect the instantaneous growth rate and the feeding preference of $\mathrm{T}$. urticae. Bt maize cultivar does not affect the abundance of phytophagous into mite communities.

\section{ACKNOWLEDGEMENTS}

We are grateful to Fundação de Amparo a Pesquisa de Minas Gerais (FAPEMIG), Coordenação de Aperfeiçoamento de Pessoal de Nível Superior (CAPES) and Conselho Nacional de Desenvolvimento Científico e Tecnológico (CNPq) for the financial supports.

\section{REFERENCES}

BOLLAND, H.R. et al. World catalogue of the spider mite family (Acari: Tetranychidae). Leiden: Bril Academic Publishers, 1998. 380p.

CRAWLEY, M.J. The R Book. Chichester (UK): John Wiley and Sons, 2012. 1076p.
DUTTON, A. et al. Uptake of Bt-toxin by herbivores feeding on transgenic maize and consequences for the predator Chrysoperla carnea. Ecological Entomology, v.27, p.441-447, 2002. Available from: $<$ http://onlinelibrary. wiley.com/doi/10.1046/j.1365-2311.2002.00436.x/abstract>. Accessed: Aug. 17, 2016. doi: 10.1046/j.1365-2311.2002.00436.x.

FADINI, M.A.M. et al. Occurrence of the phytophagous mite Catarhinus tricholaenae Keifer (Acari: Diptilomiopidae) on Bt corn cultivars. Ciência Rural, v.42, p.1524-1527, 2012. Available from: <http://www.scielo. br/scielo.php?script=sci_arttext\&pid=S0103-84782012000900001>. Accessed: Aug. 17, 2016. doi: 10.1590/S0103-84782012000900001.

FADINI, M.A.M. et al. Os ácaros são pragas do milho no Brasil? Sete Lagoas: Embrapa Milho e Sorgo, 2010. 14p. (Série Documentos, 113).

FISCHHOFF, D.A. et al. Insect tolerant transgenic tomato plants. Biotechnology, v.5, p.807-813, 1987. Available from: <http:// www.nature.com/nbt/journal/v5/n8/abs/nbt0887-807.html>. Accessed: Aug. 17, 2016. doi: 10.1038/nbt0887-807.

LIBURD, O.E. et al. The residual and direct effects of reduced-risk and conventional miticides on two-spotted spider mites, Tetranychus urticae (Acari: Tetranychidae), and predatory mites (Acari: Phytoseiidae). Florida Entomologist, v.90, p.249-257, 2007. Available from: <http:// journals.fcla.edu/flaent/article/view/75640>. Accessed: Aug. 17, 2016.

MORAES, G.J.; FLECHTMANN, C.H.W. Manual de acarologia: acarologia básica e ácaros de plantas cultivadas no Brasil. Holos: Ribeirão Preto, 2008. 288p. 
OPIT, G.P. et al. Biological control of twospotted spider mites Tetranychus urticae Koch (Acari: Tetranychidae), using Phytoseiulus persimilis Athias-Henriot (Acari: Phytoseiidae) on ivy geranium: assessment of predator release ratios. Biological Control, v.9, p.445-452, 2004. Available from: <http://www.sciencedirect. com/science/article/pii/S104996440300183X>. Accessed: Aug. 17, 2016. doi: 10.1016/j.biocontrol.2003.08.007.

PERLAK, F.J. et al. Development and commercial use of Bollgard cotton in the USA - early promises versus today reality. Plant Journal, v.27, p.489-501, 2001. Available from: <http://onlinelibrary. wiley.com/doi/10.1046/j.1365-313X.2001.01120.x/full>. Accessed: Aug. 17, 2016. doi: 10.1046/j.1365-313X.2001.01120.x.

PROKOPY, R.J. Integration in orchard pest and habitat management: a review. Agriculture, Ecosystem \& Environment, v.50, p.1-10, 1994.Available from: $<$ http://www.sciencedirect.com/science/article/pii/0167880994901201>. Accessed: Aug. 17, 2016. doi: 10.1016/0167-8809(94)90120-1.

R Development Core Team. R. A language and environment for statistical computing. Vienna: R Foundation for Statistical Computing, 2015. Available from: $<$ http://www.R-project.org > . Accessed: Mar. 09, 2015.
SCHRIJVER, A. et al. Quality of laboratory studies assessing effects of Bt-proteins on non-target organisms: minimal criteria for acceptability. Transgenic Research, v.25, p.395-411, 2016. Available from: <http:// link.springer.com/article/10.1007/s11248-016-9950-8>. Accessed: Oct. 20, 2016. doi: 10.1007/s11248-016-9950-8.

SCHULER, T.H. et al. Potential side effects of insect-resistant transgenic plants on arthropod natural enemies. Trends in Biotechnology, v.17, p.210-215, 1999. Available from: <http://www.sciencedirect.com/ science/article/pii/S0167779998012980>. Accessed: Aug. 17, 2016. doi: 10.1016/S0167-7799(98)01298-0.

STARK, J.D. et al. Reproductive potential: its influence on the susceptibility of a species to pesticides. Ecotoxicology and Environmental Safety, v.37, p.273-279, 1997. Available from: $<$ http:// www.sciencedirect.com/science/article/pii/S0147651397915529>. Accessed: Aug. 17, 2016. doi: 10.1006/eesa.1997.1552.

VAN DER GEEST, L.P.S. Aspect of physiology. In: HELLE, W.; SABELIS, M. (Eds.). Spider mites: their biology, natural enemies and control. Amsterdam: Elsevier Science, 1985. p.171-184. 